Taras Upyr, Assistant, Department of Pharmacognosy, National University of Pharmacy, Pushkinska str., 53, Kharkiv, Ukraine, 61002

E-mail: froyd1856@gmail.com

Shahm Basim Mohammed, Postgraduate Student, Department of Chemistry of Natural Compounds, National University of Pharmacy, Pushkinska str., 53, Kharkiv, Ukraine, 61002

Bashar Al-Jabbar Ali Sahlani, Postgraduate Student, Department of Biological Chemistry, National University of Pharmacy, Pushkinska str., 53, Kharkiv, Ukraine, 61002

Larysa Lenchyk, Doctor of Pharmaceutical Sciences, Associate Professor, Department of Chemistry of Natural Compounds, National University of Pharmacy, Pushkinska str., 53, Kharkiv, Ukraine, 61002

E-mail: larysa.lenchyk@gmail.com

Igor Senyuk, PhD, Associate Professor, Department of Biological Chemistry, National University of Pharmacy, Pushkinska str., 53, Kharkiv, Ukraine, 61002

E-mail: citochrom@gmail.com

Viktoria Kyslychenko, Doctor of Pharmaceutical Sciences, Professor, Department of Chemistry of Natural Compounds, National University of Pharmacy, Pushkinska str., 53, Kharkiv, Ukraine, 61002

E-mail: cncvc55@gmail.com

UDC 615.012.014

DOI: 10.15587/2519-4852.2018.135874

\title{
DYNAMICS OF EXCEPTION OF ORGANIC ACIDS FROM MIXTURE OF MEDICAL VEGETABLE RAW MATERIAL
}

\section{(C) I. Dyachok, O. Pinyazhko, O. Ivankiv}

Мета. Отримання математичних рівнянь для обчислення розміру частин різних морфологічних органів рослинної сировини для одночасного досягнення рівноваги при сумісному екстрагуванні.

Методи. 3 огляду на тенденцію до зростання рівня психопатологічних розладів, дочільним є розроблення та впровадження у медичну практику седативних засобів на основі комплексних фітополіекстрактів, одержаних із лікарської рослинної сировини. Сучасні дані про хімічний склад, фармакологічну дію, застосування в світовій медччній практиці дозволяють позитивно оцінити тенденції застосування лікарської рослинної сировини для одержання фітополіекстрактів седативної дії. Зростаючі вимоги до якості лікарських засобів рослинного походження є передумовою розроблення науково-обтрунтованих методологій отримфння фітополіекстрактів.

Результати. Представлені результати досліджень розробки методики аналітичного розрахунку розміру частинок рослинної сировини різних морфологічних органів з метою одночасного досягнення заданного ступеня вилучення органічних кислот і інших біологічно активних речовин при сумісному екстрагуванні.

Висновки. Одержані аналітичні залежності описують динаміку вилучення органічних кислот із лікарської рослинної сировини. Вирімення системи одержаних математичних рівнянь дозволяє розрахувати розмір до якого необхідно подрібнювати рослинну сировину різних морфологічних органів 3 метою одночасного досягнення заданного ступеня вилучення при сумісному екстрагуванні суміші лікарської рослинної сировини. Отримані результати свідчать про перспективність досліджень сумісного екстрагування лікарської рослинної сировини з метою одержання природніх біологічно активних речовин для виготовлення полікомпонентних фітопрепаратів

Ключові слова: лікарська рослинна сировина, органічні кислоти, динаміка вилучення біологічно активних сполук, фітополіекстракт

\section{Introduction}

Globally, there is a clear trend to higher level of psychopathological disorders, in particular a variety of psychogenic neurotic disorders. In Ukraine, the situation is complicated by various social-psychological problems, global informational oversaturation, chronic fatigue, environmental problems, the decline in the quality of life. All this leads to the onset of stress which manifests itself as fatigue, decreased performances, irritability, anxiety, worsened mood, disrupted sleep, etc. For the treatment of neurotic conditions, the most effective means are the phytogenic sedatives of plant origin due to the similarity of many biochemical processes in the cells of plant and animal origin. This property becomes particularly important when it concerns treatment and prophylactic means. The particular interest of doctors and patients in these sedatives can be explained by the minimum of contraindications and side effects [1]. 
2. Formulation of the problem in a general way, the relevance of the theme and its connection with important scientific and practical issues

Modern facts about chemical composition, pharmacological action, application in the world medical practice [2, 3] allows evaluating trends of application of medicinal plants from the point of view of the feasibility of using them as raw materials for producing polyherbal extract having sedative effect. Increasing demands to the quality of medicinal remedy of plant origin is a prerequisite for the development of advanced methodologies for obtaining polyherbal extracts and methods of their standardization. Such tasks can be solved only by developing the analytical dependences which describe the dynamic of extraction the major classes of biologically active compounds from medicinal plants which have the same pharmacological effect, but are found in different species and in different morphological organs.

\section{Analysis of recent studies and publications in} which a solution of the problem and which draws on the author.

The literature does not contain data about the calculation of particle size of the medicinal vegetable raw material with the different morphological organs (rhyzoma et radix, fructus, folium) with coextraction in order to simultaneously achieving a given degree of extraction of biologically active substances [2].

4. Allocation of unsolved parts of the general problem, which is dedicated to the article

During the extraction of the mixture of the vegetable raw material, it is important to provide optimum conditions for simultaneously achieving the balance of all biologically active substances from the mixture which will be recovered. The selection procedure is complicated by the fact that the mixture of the vegetable raw material of various morphological organs (rhyzoma et radix, fructus, folium) is often extracted.

Differences in the anatomical and morphological structure of the vegetable raw material significantly affect the kinetics of extraction. The results of experimental studies show, that with the simultaneous extrac- tion, the time of achieving equilibrium for different morphological organs of the vegetable raw material is different. This phenomenon causes the excessive time of staying in the extraction zone of this vegetable raw material, the equilibrium of which is achieved faster, which negatively affects the quality of the final product of extraction. The last is contaminated by ballast substances (cellulose, chlorophylls...), and complicates the process of separating the solid and liquid phases when extract is extracted. The swollen vegetable raw material because of a long mechanical treatment, in the extraction zone, creates a significant hydraulic resistance in the separation of solids from liquid phases.

The solution to this problem can be achieved by intensifying the process of mass transfer for this type of vegetable raw material, which time of achieving the equilibrium is much larger, compared with other types of raw materials in the mixture with the simultaneous extraction.

\section{Formulation of goals (tasks) of Article}

Obtaining the mathematical equations for calculating the size of the parts to which different morphological organs of medicinal plants are to be chopped in order to achieve a required degree of extraction of biologically active compounds when they are extracted simultaneously.

6. Statement of the basic material of the study (methods and objects) with the justification of the results. Materials and methods of research

For studying the dynamics of extraction of organic acids from chopped Valerian Root, Hop Strobile and fructus Viburni, a series of experiments in extractor with a stirrer with diameter of grinding $-3 \mathrm{~mm}$ was carried out. The $40 \%$ aqueous solution of ethanol was used as extractant. The weight ratio of the plant raw material to the volume of extractant in each of the experiments was $50 \mathrm{~g} / \mathrm{L}$. The kinetics of extraction was studied in the apparatus with stirrer at the temperature of $20 \pm 1{ }^{\circ} \mathrm{C}$. Brief value of the concentration of organic acids in the extract was determined by conductometric titration of samples of the extract for a certain period of time t. The obtained experimental kinetic data are shown in Fig. 1.

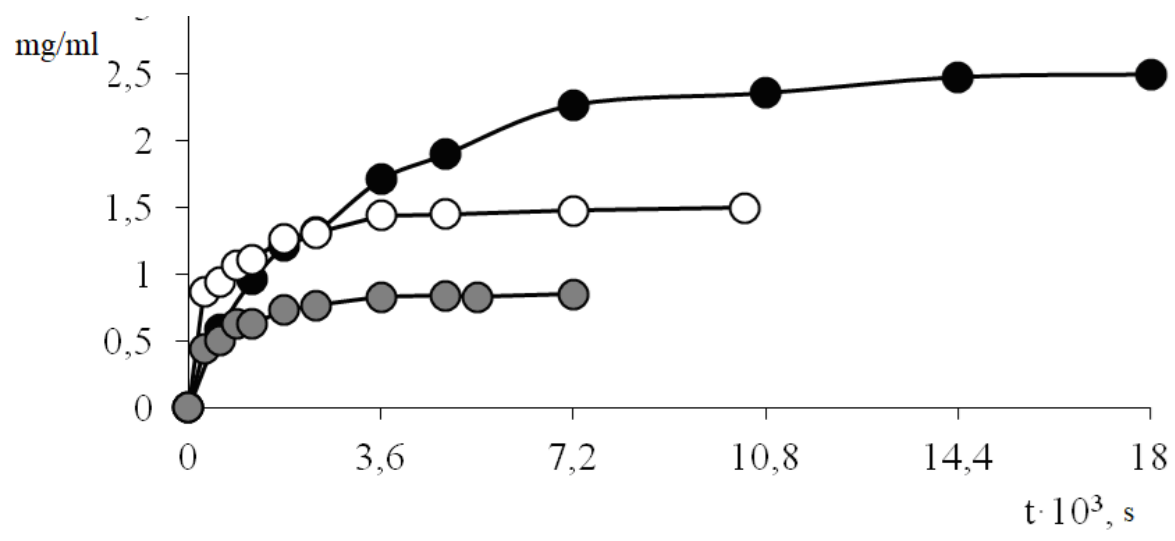

$\rightarrow$ radix Valerianae $\quad-\circ$ fructus lupulus $\quad-\infty$ fructus Viburni

Fig. 1. The kinetics of extraction of the organic acids from the medicinal plant raw material 
Fig. 1 shows that the equilibrium concentration of the organic acids reaches the largest value of $2.5 \mathrm{~g} / \mathrm{l}$ in the case of its extraction from the chopped radix Valerian. This indicates that it is the basic source of this aliphatic acid. Slightly lower value of $1.5 \mathrm{~g} / \mathrm{l}$ of equilibrium concentration of the organic acids is observed in the case of its extraction from chopped Hop Strobile (Fig. 1). At the same time, in the case of extraction of chopped fructus Viburni there is a change of the value of the equilibrium concentration of the organic acids at the level of $0.85 \mathrm{~g} / \mathrm{l}$, which indicates the low contentration of these acids in the fruit of this plant.

For the description of kinetic of relations of studied processes of extraction of organic acids from the medicinal plant raw material, the simplified equation was used [4]:

$$
C_{t}=C_{\max } \cdot\left(1-A \cdot e^{-k \cdot t}\right)
$$

where $C_{t}$ and $C_{\max }$ is the current and equilibrium concentration of the organic acids in the extract, $\mathrm{kg} / \mathrm{m}^{3}$; $\mathrm{A}$ is the coefficient of outwashing, which characterizes the number of destroyed (open) cells; $\mathrm{k}$ is the mass transfer coefficient, $\mathrm{m} / \mathrm{s}[1,5]$.

The equation (1) in a semilogarithmical coordinates takes the form (2):

$$
-\ln \left(1-\frac{C_{t}}{C_{\max }}\right)=-\ln A+k t \text {. }
$$

Using the experimental data of the kinetics of the extraction of the organic acids and equation (2) the values of under logarithmical form $\left(1-\frac{C_{t}}{C_{\max }}\right)$ were calculated, where $\frac{C_{t}}{C_{\max }}$ is the degree of extraction. The calculated values are presented in Table 1.

Table 1

\begin{tabular}{|c|c|c|c|c|c|c|}
\hline \multicolumn{7}{|c|}{ Valerian Root(size $3 \mathrm{~mm})$} \\
\hline $\mathrm{t}, \mathrm{s}$ & 600 & 1200 & 1800 & 2400 & 3600 & 4800 \\
\hline$\left(\mathrm{C}_{1} / \mathrm{C}_{\max }\right)$ & 0,24 & 0,38 & 0,48 & 0,53 & 0,68 & 0,76 \\
\hline $1-\left(\mathrm{C}_{1} / \mathrm{C}_{\max }\right)$ & 0,76 & 0,62 & 0,52 & 0,47 & 0,32 & 0,24 \\
\hline$-\ln 1-\left(\mathrm{C}_{1} / \mathrm{C}_{\max }\right)$ & 0,27 & 0,48 & 0,66 & 0,75 & 1,15 & 1,43 \\
\hline \multicolumn{7}{|c|}{ Hop Strobile (size 3mm) } \\
\hline $\mathrm{t}, \mathrm{s}$ & 300 & 600 & 900 & 1200 & 1800 & 2400 \\
\hline$\left(\mathrm{C}_{1} / \mathrm{C}_{\max }\right)$ & 0,58 & 0,63 & 0,71 & 0,74 & 0,85 & 0,87 \\
\hline $1-\left(\mathrm{C}_{1} / \mathrm{C}_{\max }\right)$ & 0,42 & 0,37 & 0,29 & 0,26 & 0,15 & 0,13 \\
\hline$-\ln 1-\left(\mathrm{C}_{1} / \mathrm{C}_{\max }\right)$ & 0,87 & 0,99 & 1,25 & 1,35 & 1,88 & 2,07 \\
\hline \multicolumn{7}{|c|}{ fructus Viburni (size $3 \mathrm{~mm}$ ) } \\
\hline $\mathrm{t}, \mathrm{s}$ & 300 & 600 & 900 & 1200 & 1800 & 2400 \\
\hline$\left(\mathrm{C}_{1} / \mathrm{C}_{\max }\right)$ & 0,52 & 0,59 & 0,74 & 0,74 & 0,86 & 0,91 \\
\hline $1-\left(\mathrm{C}_{1} / \mathrm{C}_{\max }\right)$ & 0,48 & 0,41 & 0,26 & 0,26 & 0,14 & 0,09 \\
\hline$-\ln 1-\left(\mathrm{C}_{1} / \mathrm{C}_{\max }\right)$ & 0,73 & 0,89 & 1,35 & 1,35 & 1,96 & 2,36 \\
\hline
\end{tabular}

The data for building the kinetic line of extraction of organic acids from the plant material

In Fig. 2, the kinetic lines of extraction of organic acids from the plant raw material in logarithmical coordinates are shown. Fig.2 shows that in three cases of extraction two lines can be clearly distinguished which characterize two periods. The duration of the first period of extraction corresponds to time of rapid outwashing the target organic acids from the destroyed cells and its less than $600 \mathrm{~s}$ during extraction of chopped Valerian Rootand less than $300 \mathrm{~s}$ during extraction of chopped Hop Strobile and the fructus Viburni .

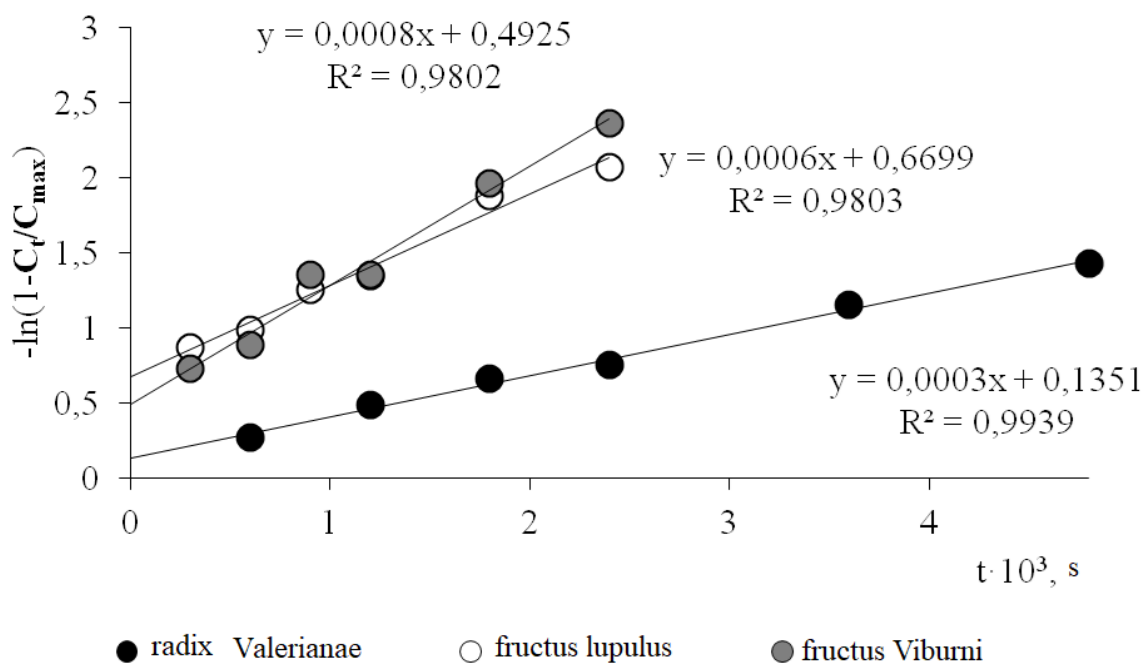

Fig. 2. Kinetic lines of extraction of the organic acids from the medicinal plant raw material 
After the mention periods of time, the slow diffusion of the target organic acids from the unparted cells, which is the evidence of the presence of second, socalled "regular" period of extraction.

On the basis of kinetic lines (Fig. 2) the values of coefficient of outwashing $\boldsymbol{A}$ and the mass transfer coeffi- cient $\mathrm{k}$ were calculated. The mass transfer coefficient $\boldsymbol{k}$ as the tangent of the slope of the line, and the coefficient of outwashing $\boldsymbol{A}$ as the distance cutting off the continuation of the straight fragment on the ordinate axis for each studied case of extraction was calculated. The values of $\boldsymbol{A}$ and $\boldsymbol{k}$ are given in Table 2 .

The parameters of kinetic model of processes of extraction of organic acids

\begin{tabular}{|l|c|c|c|c|c|}
\hline The plant raw material & $\mathbf{C}_{\mathbf{m a x}}, \mathrm{\kappa} \Gamma / \mathrm{M}^{3}$ & $\mathbf{k} \cdot 10^{4}, \mathbf{M} / \mathbf{c}$ & $-\ln (\mathrm{A})$ & $\mathbf{A}$ & $\mathrm{R}^{2}$ \\
\hline Valerian Root & 2,5 & 2,7 & 0,1351 & 0,87 & 0,9939 \\
\hline Hop Strobile & 1,5 & 6,1 & 0,6699 & 0,51 & 0,9803 \\
\hline fructus Viburni & 0,85 & 7,9 & 0,4925 & 0,61 & 0,9802 \\
\hline
\end{tabular}

The coefficients of determination of experimental data $\mathrm{R}^{2}$ in the form of kinetic lines of studied forms of the plant raw material are close to one, which indicates about an adequacy of the description of experimental data using simplified kinetic models of extraction. The final kinetic equation of extraction of organic acids from the Valerian Root, Hop Strobile and the fructus Viburni will have the form of equations (3), (4) and (5):

$$
\begin{aligned}
& C_{t}=2,5 \cdot\left(1-0,87 \cdot \exp \left(-2,7 \cdot 10^{-4} \cdot t\right)\right), \\
& C_{t}=1,5 \cdot\left(1-0,51 \cdot \exp \left(-6,1 \cdot 10^{-4} \cdot t\right)\right), \\
& C_{t}=0,85 \cdot\left(1-0,61 \cdot \exp \left(-7,9 \cdot 10^{-4} \cdot t\right)\right) .
\end{aligned}
$$

Optimization of the technological process of extraction is in establishing the optimal conditions of its realization. The maximum permissible values of the degree of the extraction $\left(C_{t} / C_{\max }\right)$ and the corresponding efficiency of target substance are the basic parameters, which characterize the conditions of extraction. To establish the optimal duration of extraction, which is equivalent to efficiency, it is reasonable to use the adequate kinetic model of this process.

The optimal duration of extraction processes of the organic acids from the studied plant raw material was determined by solving the corresponding kinetic models of extraction relatively to time $\mathrm{t}$ (3-5) with the substitution in it the values of the degree of extraction of the target acids at $95 \%$. Thus, the solution of equations (35) relatively to time $t$ takes the form of expression (6):

$$
t=-\frac{\ln (-(0,95-1) / A)}{k},[c] .
$$

Based on developed equation (6) the duration of extraction of the organic acids on the assumption of their separated conduct from the Valerian $\operatorname{Root}\left(\mathrm{t}_{1}=10600 \mathrm{c}\right)$,
Hop Strobile $\left(\mathrm{t}_{2}=3800 \mathrm{c}\right)$ and the fructus Viburni $\left(\mathrm{t}_{3}=3200 \mathrm{c}\right)$ chopped to $3 \mathrm{~mm}$ was calculated.

\section{Findings from the research and prospects of further development of this area}

The obtained experimental kinetic values show that the differences in the anatomic and morphological structure of the plant raw material significantly affect the kinetics of extraction. Thus, during the simultaneous extraction of chopped Hop Strobile and the fructus Viburni, the balance begins in the sufficiently short period of time compared to the Valerian Rootwith the same degree of disintegration, for which the balance is achieved about three times longer. A significant difference in the duration of reaching the balanced concentration of the organic acids in the case of the simultaneous extraction from the experimental chopped raw materials will be the reason of extra residence time in the area of extraction of chopped Hop Strobile and the fructus Viburni, for which the equilibrium is achieved relatively quickly. This, by-turn, will negatively affect the quality of the final polyextract because of contamination by ballast substances (cellulose, chlorophylls etc.).

This problem is solved by intensification of the process of extraction of the Valerian Root, the time to reach the balance of which is three times more compared to the Hop Strobile and the fructus Viburni with size of disintegration $3 \mathrm{~mm}$. From (6) we see that the most important factor of intensification of internal diffusional processes is the value of the mass transfer coefficient, which is directly associated with the size of the solid particles of the plant raw material. Thus, by changing the particle size of the solid phase, we can increase or decrease the time of reaching the balanced concentration BAS, therefore to achieve simultaneous established degree of extraction for different types of the plant raw material.

Using equation [5] the optimal diameter of the chopped Valerian Rootfor co-extraction of organic acids by $40 \%$ aqueous ethanol solution in the presence of chopped Hop Strobile and the fructus Viburni with size of disintegration $3 \mathrm{~mm}$ was calculated. 


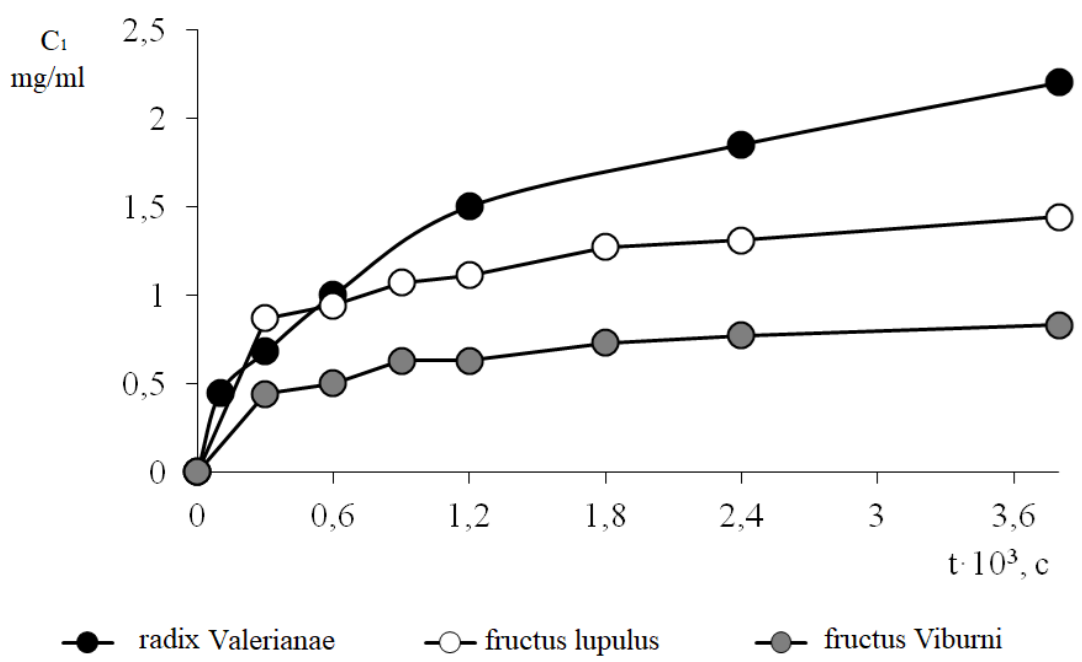

Fig. 3. The kinetics of extraction of the organic acids with the size of disintegration $1 \mathrm{~mm}$ of the Valerian Rootand 3 $\mathrm{mm}$ of Hop Strobile and the fructus Viburni

Calculation of the appropriate dimensions was realized with the computer program Mathcad using the solve function. For calculations it was accepted that the optimal length of the co-extraction corresponds to the time of extraction of the organic acids from chopped hop cones, which according to the kinetic model (6) is 3,800 s, and slightly higher than this time in the case of extraction of the fructus Viburni with the same size $3 \mathrm{~mm}$. The assumption of co-extraction of Hop Strobile and the fructus Viburni with size $3 \mathrm{~mm}$, possible under condition of disintegration of the Valerian Rootto a particle size which is about $1 \mathrm{~mm}$ was established. After disintegration of the Valerian roots to particles with proper size and the direct procedure of separation on a laboratory sieve with a holes diameter of $1 \mathrm{~mm}$, an experiment was conducted and the kinetics of extraction of the organic acids by $40 \%$ aqueous ethanol solution in the apparatus with stirrer was investigated. The obtained experimental kinetic data is shown in Fig. 3.

Fig. 3 shows that increasing degree of disintegration of the Valerian Rootin three times has led to a corresponding reduction of the extraction time of the organic acids to the balanced value. Therefore, we can assume that the proposed method of analytical calculation of the size of the particles of plant raw material, for their co-extraction have a great practical significance.

\section{Conclusions}

1. Fig. 3 shows that increasing degree of disintegration of the Valerian Root in three times has led to a corresponding reduction of the extraction time of the organic acids to the balanced value.

2. We can assume that the proposed method of analytical calculation of the size of the particles of plant raw material, for their co-extraction have a great practical significance on a production for the management of processes of the compatible extracting with bringing digital technologies in.

3. The offered algorithm of analytical calculation can be applied for the calculation of sizes of particles for compatible extracting of other multicomponent mixtures of plant raw materials which composition includes rhyzoma et radix, fructus, folium.

\section{References}

1. Kiseleva T. L. The age-old traditions of traditional medicine in modern sedative and anxiolytic drugs // VIII Russian National Congress Man and Medicine. Materials of the satellite symposium. Moscow: Galena AS, 2001. P. 8-21.

2. Dyachok V. V., Ivankov O. I., Dyachok I. L. Calculation of the kinetics of the coexistence of medicinal medicinal vegetable raw materials // Pharmaceutical Journal. 2012. Issue 4. P. 90-95.

3. Dyachok I. L., Pinyashko O. R. The development of quantitative determination method of organic acids in complex poly herbal extraction // Current issues in pharmacy and medicine: science and practice. 2016. Issue 2. P. 48-51. doi: http://doi.org/ 10.14739/2409-2932.2016.2.71129

4. Ponomarev V. D. Extraction of medicinal vegetable raw materials. Moscow: Medicine, 1976. 204 p.

5. Ivanov A. I. Principles of ensuring the quality of production of medicines at the present stage of development of the world pharmaceutical market // Pharmacy. 2009. Issue 2. P. 21-23.

6. Litvinova N. V. Ecological potential of innovative production of phytopreparations // Liki of Ukraine. 2009. Issue 7. P. 28-30.

7. Minin S. A. Chemistry and Technology of Phytopreparations. Moscow: GEOTAR - Media, 2004. 560 p.

8. Mitrofanova I. Yu., Yanitskaya A. V., Butenko D. V. Methodological bases of the choice of plant objects as sources of phytopreparations // Fundamental research. 2012. Issue 10. P. 405-408.

9. Technology and standardization of medicines. Vol. 1 / V. P. Georgievsky, F. A. Konev (Eds.). Kharkiv: LLC "Riger", 1996. $778 \mathrm{p}$.

10. Shirokova I. The market of herbal medicines: trends, challenges and forecasts // Remedium. Journal About the Russian Market of Medicines and Medical Equipment. 2013. Issue 4. P. 26-32. doi: http://doi.org/10.21518/1561-5936-2013-4-26-32 
Dyachok Iryna, assistant, Department of Pharmacology, Danylo Halytsky Lviv National Medical University, Pekarska str., 69, Lviv, Ukraine, 79010

E-mail: irynalvivnadyachok@gmail.com

Pinyazhko Oleh, MD, Professor, Department of Pharmacology, Danylo Halytsky Lviv National Medical University, Pekarska str., 69, Lviv, Ukraine, 79010

E-mail: olehpinyazhko@gmail.com

Ivankiv Oksana, PhD, Associate Professor, Department of Pharmacology, Danylo Halytsky Lviv National Medical University, Pekarska str., 69, Lviv, Ukraine, 79010

E-mail: oksanalvivna@gmail.com 